\title{
Visual Rhetoric and the Power of Imagery: A Brief Lesson in the Rhetorical Power of Images and the Need for phronesis and krisis in the Teaching of Visual Rhetoric
}

\author{
Visuality Design in and for Education
}

\author{
Jens E. Kjeldsen | ORCID: 00oo-0oo2-5940-6940 \\ Professor of rhetoric and visual communication, Department of Information \\ Science and Media Studies, University of Bergen, Bergen, Norway \\ jens.kjeldsen@uib.no
}

\begin{abstract}
Since the ancient rhetoricians, humans have awarded imagery, the visual, and the vivid an extraordinary effect on emotions and memory. Such assumptions have led to iconophobia, iconoclasm, and myths about the special power of images. The issue of the power of pictures, however, is more complicated. As all other kinds of rhetorical utterances, the visual can be both powerful and powerless depending on the circumstances. For many pictures, the rhetorical power lies not mainly in their political deliberation, but instead in their nature as demonstrative or epideictic rhetoric: a rhetoric that does not primarily advocate immediate change, but tries to increase adherence to existing view-points, attitudes and values. Even though visual rhetoric may perform a powerful address to those who are already convinced, it does not necessarily hold much power over adversaries and sceptics. This article argues that when teaching visuality and the power of imagery, educators ought to help young pupils - and the citizenry in general - not only to decode visual communication, but also to interpret and evaluate it. The first requires knowledge about rules of visual literacy, the second requires not only critical thinking, but also situational and cultural knowledge, as well as sound judgment.
\end{abstract}




\section{Keywords}

visuality design - rhetoric - visual rhetoric - images - power - teaching visuality epideictic - phronesis

- This article is part of the special topic 'Visual Worlds of Education as Research Designs', edited by Åsta Birkeland, Liv Torunn Grindheim and Chang Liu.

\section{Introduction: Teaching Visuality Requires Knowledge of Visual} Power

What is the power of pictures? More important perhaps, why is this question important for education and pedagogy? While a great amount of research into visual literacy, semiotics and multimodal communication has been carried out, communicated in textbooks and introduced both in teacher's education and in the school system (e.g. Bateman, Hiippala, \& Wildfeuer, 2017; Jewitt, 2014; Kress \& Van Leeuwen, 2006), the question of visual and multimodal power seems to have been either neglected or misunderstood - at least in teaching. Thus, if we are concerned with the role of visuality in our time, we should pay attention to what the evidence says about visual power.

This is not just a matter of examining the power of the visual, but also a matter of understanding the concept of power altogether. When thinking of rhetoric - verbal or visual - we might tend to think that the communicator (the orator) is the powerful part of the equation. However, anyone who has attempted to persuade anyone else quickly learn that most of the power lies with the audience. This, I suggest, may be especially the case with visual communication, and research points to the same (Domke, Perlmutter, \& Spratt, 2002; J. Kjeldsen \& Hess, 2021; J. E. Kjeldsen \& Andersen, 2018). Thus, when teaching visuality, we ought to help our young pupils - and the citizenry in general - not only to decode visual communication, but also to interpret and evaluate it. The first requires knowledge about rules of visual literacy, the second requires not only critical thinking, but also situational and cultural knowledge, as well as sound judgment.

\section{$2 \quad$ Examples of Visual Power}

A recent example that seems to demonstrate the power of the visual without doubt, was the images of the Minneapolis police officer Derek Chauvin with 
his knee on the neck of George Floyd in May 2020. Mr. Floyd was gasping for air, saying he could not breathe. Finally, Floyd became quiet, lying lifeless on the ground. It seemed an open-and-shut-case, because the images made it all clear: Derek Chauvin killed George Floyd. However, the pictures do not show a murder. They show a police officer with his knee on another man. We needed the words to tell us why and how this was murder. Pictures never prove anything in themselves.

More than twenty years ago, in 1991, the acquittal of four police officers demonstrated this. The officers had badly beaten up the lorry driver Rodney King. An observer captured it all on camera. King lying on the ground while the officers kicked him and hit him with their batons. Everybody thought the message of the video was obvious. But it wasn't obvious.

In court the lawyer for the police officers showed the movie over and over again, telling the jury what they really saw: a violent aggressive man, under the influence of drugs, trying to attack the police officers. The words of the lawyer framed the meaning. The words formed what the jury thought they saw, and the officers were acquitted. The public saw it differently, and Los Angeles erupted in riots (Tomasulo, 1996).

This teaches us that we cannot take the power of imagery for granted, because the power of imagery always depends. It depends on the words that frame them, it depends on the audience watching, it depends on the situation the audience is in, and it depends on the context and culture the interaction occurs in. This situational and rhetorical insight not only has consequences for our understanding of the power of the visual, but also for how we should approach the teaching of the rhetoric and power of the visual. Understanding the workings and power of visual and multimodal rhetoric requires a humanistic perspective with situational and cultural awareness and the ability for sound human judgment.

The Humanistic Perspective: phronesis and krisis

Understanding the importance of such circumstances, and applying and using such knowledge, is a form of critical rhetorical insight. This does not come with a fixed formula for decoding or analyzing.

Understanding is more than a vocabulary for a visual grammar or lists of meaning-making in multimodal semiotics. So, understanding the power of imagery requires discovery through critical thinking. It is a discovery that requires ability for practical wisdom and for human judgment, or as Aristotle called it phronesis and krisis (Aristoteles \& Kennedy, 2007). 
Such phronesis, practical wisdom, and krisis, human judgment, cannot be taught in a narrow sense of the word teach. We do not acquire wisdom and judgment through a specific method. We acquire it by having access to a variety of insights and broad knowledge, and by assuming an open and reflective attitude. Wisdom and judgment must be cultivated through a continuous interaction with a variety of situations, forms of communication, and cultures and opposing viewpoints.

One cannot understand verbal rhetoric through grammatical analysis of words alone. In the same way one cannot understand the power of the visual just through semiotic decoding of texts. Instead, understanding both verbal and visual rhetoric requires aesthetic sensitivity, cultural and historical knowledge.

Without this we will repeat myths about rhetoric, visuality, and power that goes all the way back to ancient times. More than ever, in a world of conspiracy theory, fake news, and deep fakes the humanistic qualities of rhetorical interpretation are essential.

\section{Myths about the Visual Feeding the Structure of Suspicion}

When it comes to the power of imagery, for instance, our ability for wisdom and judgment requires that we know which stories are factual, and which are fiction. Take the advertising man James Vicary. In 1957 he announced that during a movie in a cinema, he had flashed the slogans "Drink Coca-Cola" and "Eat Pop-corn", too fast for conscious perceptions. He claimed that he had subliminally influenced the audience so that the sales of Pop-Corn had gone up 18,1\%, and the sales of Coca-Cola had gone up 57.7\%. The news caused an uproar - fear and panic for subconscious persuasion erupted. But the whole thing was a fraud. The cinema said that such an experiment had not been carried out. In short: Subliminal advertising doesn't work (Rogers, 1992).

In 1960, a new myth arose. A television debate between Richard Nixon and John F. Kennedy was aired both on radio and television. A study allegedly proved that the television viewers saw Kennedy as the winner, while the radio listeners saw Nixon as the winner. What was the explanation? In short: the myth says that Kennedy looked young, handsome, and confident, while Nixon looked old, tired, and insecure. This was taken as proof that the visual is more powerful than the verbal. But is this really true? If it was, it would be more persuasive to see Kennedy without sound, than to hear Nixon without images. But common sense and research studies tell us that the myth doesn't hold up (Kraus, 1996; Vancil \& Pendell, 1987). 
One final myth worth mentioning is often found in management literature. It claims that in interpersonal communication our words only carry $7 \%$ of the influence, voice and tone carry $38 \%$, and body language an astonishing $55 \%$. Like the other myths this sounds counter-intuitive - which of course is part of the appeal. And like all myths it has sustained because most of us do not really check the facts. The numbers are from studies of nonverbal communication by psychologist Albert Mehrabian (Mehrabian, 1972). He has himself said that the numbers are misused. The numbers only apply when there is inconsistency between the spoken and the non-verbal and when people are talking about feelings and attitudes. Furthermore, it doesn't make sense to divide human communication in percentages. When a teacher, for instance, is talking to her pupils, do her words only account for 7 percent? Of course not. The myth has also been debunked in research literature (Pamela, 2010).

The stories about Vicary, the Kennedy-Nixon debate, and Mehrabian's numbers reveal two assumptions about imagery and visual rhetoric that goes all the way back to the ancient rhetoricians, and still feed beliefs and myths about rhetorical communication. Take the ancient text, Encomium to Helen. This is a showpiece by the sophist and rhetorician Gorgias. It was meant to show his ability to make anybody believe anything. The Encomium is probably the first known thesis in Western culture exploring the power of rhetoric and visual communication. In this text Gorgias (Gorgias, 1982) writes:

And some people ... on seeing frightful things, have also lost their presence of mind at the present moment; fear so extinguishes and expels thought. And many have fallen into groundless distress and terrible illness and incurable madness; so deep does sight engrave on the mind images of actions that are seen.

Since before the beginning of our time, then, the visual and vivid have been assumed to have an extraordinary effect on the emotions and memory of humans. These assumptions have led to iconophobia, iconoclasm, and myths about the special power of images (Finnegan \& Kang, 2004; Freedberg, 1989; Hariman \& Lucaites, 2016; J. E. Kjeldsen, 2007; J. E. Kjeldsen \& Andersen, 2018). First, imagery is thought to have power over other forms of expression, in the sense that the visual in multimodal communication will dominate the other forms of expression: "In the contest between evocative pictures and spoken words, pictures usually win" (Jamieson, 1992, p. 103). Second, imagery is thought to influence in a stronger way than other forms of expression. A picture is perceived to be more powerful than a text. In social psychology, the vividness hypothesis suggests that our "inferences and behaviour are so much 
more influenced by vivid, concrete information, than by pallid and abstract propositions of substantially greater probative and evidential value" (Nisbett \& Ross, 1980, p. 144).

Thus, since the beginning of rhetorical thought, vivid and visual communication has been viewed as a problem to truth, freedom, and ethics. The visual has been considered as false, superficial, manipulation, emotion, only form, powerful, magic, belonging to the unconscious, and wholly irrational. Two thousand years of attacks on imagery and the visual reveals a structure of suspicion, which connects the many forms of suspicion and fear with each other (see table 1):

TABLE 1 Structure of suspicion

\begin{tabular}{ll}
\hline truth and clarity & falseness and confusion \\
rationality (sense) & emotionality (emotion) \\
logos & pathos \\
powerless utterance & powerful utterance \\
powerful audience & powerless audience \\
audience convinced by free will & audience persuaded against free will \\
influence effected consciously & influence effected sub- or unconsciously \\
\hline
\end{tabular}

SOURCE: PARTLY FROM KJELDSEN, 2OO7, P. 17-18

The structure of suspicion tends to feed the two dominant assumption of visual power. First, that visuals have power over other forms of expression. When someone is talking - the claim is - our attention is with the body and voice, and we forget about the words. Second, that visuals have especially strong power over humans' thoughts and actions compared to other forms of communication.

\section{$5 \quad$ The Power of Images}

It is true, that imagery may be used to mislead, to manipulate and to influence our emotions. However, in the history of mankind, nothing has misled as much as the use words and pallid facts. We probably all remember the old quote about the three kinds of lies: Lies, damned lies, and statistics. Contemporary research nuances the validity of the structure of suspicion, provides a more skeptical view of the power of images and suggest that we reject the emotions and propositions of imagery when we disagree with the propositions, we believe they 
make (J. E. Kjeldsen, 2015, 2017; J. E. Kjeldsen \& Andersen, 2018). Instead, the power of images seems to lie especially in the "pre-existing values, cognitions and feelings" of the audience (Domke et al., 2002, p. 147). If this is the case, then the rhetoric of images should not only - or primarily - be connected to the ability to persuade, but especially to the ability to prime and trigger already existing cognitive and affective dimensions (Domke et al., 2002; Perlmutter, 1998). Since the 1970s media- and reception studies have taught us that viewers are active audiences, they interpret, evaluate, and they oppose what they see (Morley \& Brunsdon, 1999).

Recently, cognitive psychology has taught us that reason and emotion are connected. Sensible thinking simply cannot happen without contact to our emotions (Damasio, 1996). This provides scientific support for the ancient rhetorical claim, of the unity of thinking and feeling. It confirms the connection between rationality, emotionality, and trust between logos, pathos and ethos. Recently, rhetorical audience studies have begun examining how people actually receive and engage with verbal and multimodal rhetoric (J. Kjeldsen \& Hess, 2021; J. E. Kjeldsen, 2016, 2018). This research helps us understand that the power of the visual is more complicated and nuanced than the myths and everyday beliefs suggest.

The results do not claim that visuals are powerless, but they do suggest that the audience also have power, and that visual and multimodal communication exercise different kinds of influence depending on the situation and audience.

Take the disturbing images of the dead Syrian toddler Alan Kurdi washed up on a Turkish beach in 2015. These photographs shocked and moved people all around the world. There is no doubt that they had emotional effect. Newspapers all around the world proclaimed that the photographs changed us all. In the newspaper The Telegraph UK Prime Minister David Cameron's emotional change of heart in the immigration policy was put forward as evidence for the political power of the picture (J. E. Kjeldsen, 2017, p. 73). ${ }^{1}$

But the change was short lived. Immigration policy never changed fundamentally, and only months later strict measures were reinforced. In some countries even stricter than before. This is in line with the above-mentioned research suggesting that viewers will reject the emotions and propositions of news photographs when they disagree with their rhetoric.

If this is the case, then the rhetoric of images lies not primarily in their ability to persuade, but in their ability to confirm and reinforce. Images have the power to prime, trigger, and strengthen already existing cognitive and affective

1 See https://www.telegraph.co.uk/news/uknews/immigration/11842643/The-refugeeswelcome-fad-will-do-more-harm-than-good.html (last accessed November 1, 2021). 
dimensions. If on the other hand, a viewer disagrees with what you think an image claims then she or he will reject this claim despite its emotional appeal. The emotional appeal may even push the viewer even further away. This was evident in a study of the reception of the Alan Kurdi images which examined comments to the image in newspapers, comments on Facebook, and interviewed informants (J. E. Kjeldsen \& Andersen, 2018). It was obvious that certain people actively rejected the message of the images.

The UK newspaper The Telegraph wrote on September 3, 2015 that "the refugees welcome fad will do more harm than good." ${ }^{2}$ The images of Kurdi, they claimed, were being used to accuse realistic politicians of being heartless. In a similar fashion, commentator in The Mail, Richard Littlejohn, wrote on September 4, 2015: "This child's death was tragic, but it was not our fault."

Based on the press coverage, comment fields and research interviews, the study of the reception of the Kurdi images revealed four types of rejecting response to the images. In general terms, we may say that humans can reject images of suffering immigrants in these four ways:

1. Rejecting the veracity of the pictures

2. Rejecting that the migrants are really refugees

3. Accepting the tragedy, but rejecting responsibility

4. Accepting the tragedy and taking (some) responsibility, but arguing that accepting great numbers of migrants and refugees is not the right answer In more colloquial terms, we may say that people's rejection of such images make them say:

1. The images are fake

2. These people are not real refugees

3. Yes, it's bad, but it is not my fault

4. Yes, it is bad, and it is partly our fault, however it would still be better not to let all these refuges come to Europe

The lesson learned by these results and the mentioned theory is relevant both for the study of the power of images and for the education of visual literacy and citizenship: When pictures are used to argue, we argue back. When we feel images argue, and when we disagree with the visual argument, then we will argue back.

The more emotional the visual argument is, the more forceful viewers will reject it. They may even use other images to counter the visual rhetoric we

2 See https://www.telegraph.co.uk/news/uknews/immigration/11842643/The-refugeeswelcome-fad-will-do-more-harm-than-good.html (last accessed November 1, 2021).

3 See http://www.dailymail.co.uk/debate/article-3221855/RICHARD-LITTLEJOHN-child-sdeathtragic-not-fault.html (accessed November 1, 2021). 
disagree with. Take an article from The Express published on September 10, $2015 .{ }^{4}$ The title proclaims: "Are these happy young men really timid souls fleeing war and persecution?" The image shows well dressed, happy young men on the beach of the Greek Island of Lesbos holding their cell phones high, while taking selfies. The image functions as a counter-argument, to the images of Alan Kurdi. The Kurdi-images were used as a part-for-whole-argument generalizing from the individual pain of a dead child to the pain of all immigrants and the disaster of the immigration crisis. As a rejection of the implicit claims in the use of the Kurdi-images, the photograph of these young men was used as a part-for-whole argument (lat. pars-pro-toto) generalizing from the carelessness of these asylum seekers, to all the immigrants arriving in Europe.

All this does not mean that pictures do not have rhetorical power. They do. But we have not really understood rhetorical power if we just claim that pictures are powerful or if we just say that they are more powerful than words.

The special power of pictures, I suggest, lies in their ability to display values, emotions, and worldviews we already hold. Pictures are good at confirming and reinforcing what we already think and feel. If you think police violence is problem, then the picture of Derek Chavin and George Floyd demonstrates it without the need of words. If you believe that Europe have let the refugees down, then this is what you will think when seeing the image of Alan Kurdi. On the other hand, if you think that people seeking asylum in Europe are not really refugees, the image of the young men on the beach proves it.

In verbal rhetoric such a display of existing, shared values, is known as epideictic rhetoric. From ancient Greek, the work epideictic actually means to display or point out. It is an act of demonstrating or showing to the audience, which is exactly what pictorial rhetoric does. Such rhetoric - whether it is verbal or visual - creates common meaning and identity. Visual epideictic rhetoric displays and reinforces the values and viewpoints that a group already share.

A special rhetorical power of pictures, then, is their ability to display events before us as though we experience them ourselves confirming what we already think we feel, believe, and know. Power depends on situation and culture. Therefore, understanding the power of pictures, requires an understanding of the rhetorical situation, the facts in the specific case and a sensitivity to the culture the communication belongs to. It becomes especially important then, when dealing with visual rhetoric to teach our youth to be critical to images in general and particularly to the images that seem to confirm what we think we already know.

4 See http://www.express.co.uk/news/world/6o3511/Migrant-crisis-refugees-take-selfie-photoGreekboat-Lesbos-Syria-war (last accessed November 1, 2021). 
Of course, decoding and interpreting imagery requires knowledge of semiotics and visual grammar. But such technical knowledge is useless without situational, cultural, and historical awareness. Such awareness provides us with practical wisdom and sound judgment: with pronesis and krisis.

If we wish to explore the worlds of visual education, we should bear this in mind. Because the teaching of rhetoric and the power of pictures, is not a technical art. Teaching rhetoric and the power of pictures is a humanistic art, and this humanistic art should be part of the worlds of visual education.

\section{References}

Aristoteles, \& Kennedy, G. A. (2007). On rhetoric: a theory of civic discourse (2nd ed. ed.). New York: Oxford University Press.

Bateman, J. A., Hiippala, T., \& Wildfeuer, J. (2017). Multimodality: foundations, research and analysis a problem-oriented introduction. Mouton Textbook. Berlin, Germany: De Gruyter Mouton.

Damasio, A. R. (1996). Descartes' error. Emotion, reason, and the human brain. London: Papermac.

Domke, D., Perlmutter, D., \& Spratt, M. (2002). The primes of our times?: An examination of the 'power' of visual images. Journalism, 3(2), 131-159. doi:10.1177/146488490200300211.

Finnegan, C. A., \& Kang, J. (2004). "Sighting" the Public: Iconoclasm and Public Sphere Theory. Quarterly Journal of Speech, 9o(4), 377-402.

Freedberg, D. (1989). The power of images. Studies in the history and theory of response. Chicago: University of Chicago Press.

Gorgias. (1982). Encomium of Helen. Bristol: Bristol Classical Press.

Hariman, R., \& Lucaites, J. L. (2016). The public image: photography and civic spectatorship. Chicago, Illinois: University of Chicago Press.

Jamieson, K. H. (1992). Dirty politics. Deception, distraction, and democracy. New York: Oxford University Press.

Jewitt, C. (2014). The Routledge handbook of multimodal analysis (2nd ed. ed.). Oxon: Routledge.

Kjeldsen, J. E. (2007). Øjets frygt og ærefrygt. Om Helenas pris og modviljen mod retorik og visuelle appeller. Rhetorica Scandinavica(41), 10-25.

Kjeldsen, J. E. (2015). The Rhetoric of Thick Representation: How Pictures Render the Importance and Strength of an Argument Salient. Argumentation, 29(2), 197-215. doi:10.1007/s10503-014-9342-2.

Kjeldsen, J. E. (2016). Studying Rhetorical Audiences. Informal Logic, $36(2)$. 
Kjeldsen, J. E. (2017). The rhetorical and argumentative dimensions of press photography. In A. Tseronis \& C. Forceville (Eds.), Multimodal Argumentation and Rhetoric in Media Genres (pp. 52-8o). Amsterdam: John Benjamins.

Kjeldsen, J. E. (Ed.) (2018). Rhetorical Audiences and the Reception of Rhetoric. Exploring Audiences Empirically. Cham, Switzerland: Palgrave Macmillan.

Kjeldsen, J. E., \& Andersen, I. (2018). The Rhetorical Power of News Photographs: A Triangulatory Reception Approach to the Alan Kurdi Images. In J. E. Kjeldsen (Ed.), Rhetorical Audience Studies and Reception of Rhetoric: Exploring Audiences Empirically (pp. 309-333). Cham, Switzerland: Palgrave Macmillan.

Kjeldsen, J., \& Hess, A. (2021). Experiencing multimodal rhetoric and argumentation in political advertisements: a study of how people respond to the rhetoric of multimodal communication. Visual communication, 20(3), 327-352. doi:10.1177/ 14703572211013399 .

Kraus, S. (1996). Winners of the first 1960 televised presidential debate between Kennedy and Nixon. Journal of Communication, 46(4), 78-96. doi:10.1111/j.146o-2466.1996. tbo1507.x.

Kress, G., \& Van Leeuwen, T. (2006). Reading images. The grammar of visual design (2nd ed. ed.). London: Routledge.

Mehrabian, A. (1972). Nonverbal communication. Chicago: Aldine-Atherto.

Morley, D., \& Brunsdon, C. (1999). The Nationwide Television Studies. Routledge Research in Cultural and Media Studies. London: Routledge.

Nisbett, R. E., \& Ross, L. (1980). Human inference: strategies and shortcomings of social judgment. Englewood Cliffs, N.J: Prentice-Hall.

Pamela, T. (2010). Debunking the body language myth. Training and development in Australia, 37(5), 18.

Perlmutter, D. D. (1998). Photojournalism and foreign policy: icons of outrage in international crises. Westport, Conn: Praeger.

Rogers, S. (1992). How a publicity blitz created the myth of subliminal advertising. Public relations quarterly, 37 (4), 12.

Tomasulo, F.P. (1996). "I'll see it when I believe it." Rodney King and the prison-house of video. In V. Sobchack, The Persistence of History. Cinema, Television and the Modern Event. Routledge. New York \& London.

Vancil, D. L., \& Pendell, S. D. (1987). The myth of viewer-listener disagreement in the first Kennedy-Nixon debate. Central States Speech Journal, 38(1), 16-27. doi:10.1080/10510978709368226. 